\section{Genomic DNA Isolation and Purification of Two Endemic Medicinal Plants (Pterocarpus Santalinus Linn.F \& Pimpinella Tirupatiensis Bal\&Subr) of Seshachalam Hills, Tirumala.}

\author{
S. Vipranarayana \\ Department of Environmental Sciences, Sri Venkateswara University, \\ Tirupathi-517 502, A.P., India \\ T.N.V.K.V.Prasad \\ Institute of Frontier Technology, Regional Agricultural Research Station, \\ Acharya N G Ranga Agricultural University, Tirupati-517 502, A.P., India
}

\section{A. Rajinikanth}

Department of Environmental Sciences, Sri Venkateswara University, Tirupathi-517 502, A.P., India

T. Damodharam (Corresponding author)

Department of Environmental Sciences, Sri Venkateswara University, Tirupathi-517 502, A.P., India

Tel: 91-929-064-8816 E-mail: thotidamodhram@yahoo.co.in

Received: April 10, 2012 Accepted: April 23, 2012

doi:10.5296/jbls.v4i1.1618 URL: http://dx.doi.org/10.5296/jbls.v4i1.1618 


\section{Abstract}

Ptercarpus santalinus is an important endemic medicinal plant with high medicinal values that interfere with DNA extraction procedures and qualitative, quantitative agaros gel electrophoresis. An effective and low-cost protocol for isolating genomic DNA from the roots of Pterocarpus santilinus and Pimpinella tirupatiensis was described in this paper. It involved a modified CTAB method with distilled water pretreating samples. The $\mathrm{A}_{260} / \mathrm{A}_{280}$ absorbance ratio of extracted DNA was found to be free from polysaccharide, poly-phenols and tannins contaminants ranged from 2.2 to 2.8 within the high level of purity.

Keywords: Ptercarpus santalinus, DNA extraction, Secondary metabolites

Abbreviations: CTAB, hexadecyltrimetylammonium bromide

\section{Introduction}

The genus Pterocarpus satalinus Linn.F. belongs to the family papilionaceae/ fabaceae and popularly known as 'Red sander's (Naidu et al. 2001). It was traditionally used in treatment for headache, skin diseases, fever, boils, scorpion-sting and to improve sight (Chopra et al. 1956; Latheef et al., 2008). Previous chemical constituents revealed the presence of triterpenes, isoflavone, glucosids, savinin and calocedrin (Krishnaveni et al. 2000). The methanolic extract of Pterocarpus santalinus was capable of scavenging the free radicals and inhibited the tested bacteria, suggested the potential antibacterial and antioxidant effect (Krishnamurthy et al. 2011). Pterocarpus santalinus Linn.F. is an endemic and endangered species of Andra Pradesh, Seshachalam hills in India.

Pterocarpus santalinus is endemic to Eastern ghats of Andhra Pradesh and in the adjoining regions of Karnataka and Tamil Nadu. The Heartwood is also used for treating skin diseases, bone fracture, leprosy, ulcers and mental aberration. Wood paste applied on skin eruptions, inflammations and forehead to relieve headache, wood powder is used to control hemorrhage, bleeding piles and inflammation (Ravi Kumar et al. 2000).

Pterocarpus santalinus is one of the plants used for treatment of diabetes. Molecular markers provide the best estimates of genetic diversity that are independent of effect of various environmental factors. RAPD techniques were successfully used in determining genetic diversity in various plants from western ghats such as Dendrocalamus strictus and Bambusa bambos (Biradar et al., 2005), Gnelia arborea (Shankar et al., 2009), Sweet sorghum (Kacahapur et al., 2009) and Allium stracheyi (Ranjan et al., 2010). Pterocarpus santalinus being a tree species is a difficult plant for DNA isolation due to its high polyphenolic content that may interfere with the quantity and quality of DNA. We report here the modified CTAB protocol derived from the method that was originally developed for other plants (Doyle and Doyle, 1987). Modification was made to yield sufficient and pure DNA (Staden et al., 2008). The protocol optimizes the various conditions for RAPD such as annealing temperature, DNA concentration and the amount of Tag Polymerase (Padmalatha and Prasad 2006). 


\section{Material and Methods}

\subsection{Isolation of Genomic DNA from Plant Tissue}

The isolation of Genomic DNA was extracted from 8 months-old young leaves of Perocarpus santalinus and Pimpinella tirupatiensis maintained at the BIOTRIM, Forest Research Institute, Tirupati. Initially, the available protocol was used several times but poor quality and quantity of DNA was extracted. Hence, modifications were made in the protocol viz., the use of higher volume of extraction buffer, increased incubation temperature, use of polyvinyl pyrrolidone repetition of purification step with chloroform: isoamyl alcohol and washing of DNA pellet with wash buffer and ethanol (95\%). The detailed modified protocol is given below.

\subsection{Solutions and Reagents}

2 X CTAB Buffer (EB): 2\% CTAB (w/v), 100 mM Tris-HCl (pH 8.0), 20 mM EDTA (pH 8.0), $1.4 \mathrm{M} \mathrm{NaCl}, 1 \%$ (w/v) PVP (Polyvinylpyrrolidone), Autoclaved $\mathrm{CHCl}_{3}$ - IAA: Chloroform: isoamyalcohol (24:1),10\% CTAB solution: 10\% CTAB Buffer (CPB): 1\% CTAB, 50 mM Tris-HCl (pH 8.0), 10 mM EDTA (pH 8.0) Ethanol: absolute or 95\% ethanol, Salt solution: $3 \mathrm{M}$ sodium acetate.

\section{Procedure:}

All the steps were carried out at room temperature. Rinse harvested leaves with autoclaved water and blot dry. Grind $2 \mathrm{~g}$ leaves to a fine powder. Extract in 3 volumes of EB and incubate at $65^{\circ} \mathrm{C}$ for $30 \mathrm{~min}$. Centrifuge at $10,000 \mathrm{rpm}$ for $15 \mathrm{~min}$ and collect supernatant. Extract with equal volumes of $\mathrm{CHCl}_{3}$ : IAA (24:1), collect upper aqueous Phase after centrifugation at 8,000 rpm for $10 \mathrm{~min}$. Add one-tenth volume of warm $\left(55^{\circ} \mathrm{C}\right) 10 \% \mathrm{CTAB}$ solution and re-extract with $\mathrm{CHCl}_{3}$ : IAA as above. Add at least 1.5 volume of CPB buffer, mix gently and collect the precipitate by centrifugation at $10,000 \mathrm{rpm}$ for $10 \mathrm{~min}$. Precipitate the DNA by adding 2 volumes of ethanol and one-tenth volume of $3 \mathrm{M}$ sodium acetate. Incubate the sample at $-20^{\circ} \mathrm{C}$ for $15 \mathrm{~min}$. Centrifuge the sample at $10,000 \mathrm{rpm}$ for $15 \mathrm{~min}$. Collected the pellet, air dried and added 30-50ul of nuclease free water to dissolve the pellet.

\subsection{Purification of Isolated DNA}

3M Sodium Acetate (pH-5.2), Absolute Alcohol, Nuclease free water

\section{Procedure:}

Add $1 \mu 1$ of RNase to the DNA mixture and incubate the mixture at $37^{\circ} \mathrm{C}$ for one hour. After incubation, add $1 / 10^{\text {th }}$ volume of $3 \mathrm{M}$ Sodium acetate $(\mathrm{pH}-5.2)$ and 2.5 volumes of absolute alcohol (90\%). Keep it on ice for $10 \mathrm{~min}$. Spin at 12,000 rpm for 15- 20 minutes. Collect the pellet and wash it with $150 \mu 1$ of $70 \%$ ethyl alcohol. Keep at room temp for 15-20 minutes. Then the pellet was air dried and dissolves in appropriate volume of Nuclease free water.

\section{AGAROSE GEL ELECTROPHORESIS}




\subsection{Solutions and Reagents}

50X TAE BUFFER, 2M-Tris, 1M-Acetate, 50mM- EDTA, Dilute this to 1X TAE with distilled water. Agarose, Ethidium Bromide $(10 \mathrm{mg} / \mathrm{ml})$, Bromophenol Blue: 0.025\% Bromophenol Blue, $10 \%$ Glycerol

\section{Procedure}

Make a $1 \%$ agarose solution by dissolving $0.2 \mathrm{gms}$ agarose in $20 \mathrm{ml}$ of $1 \mathrm{X}$ TAE. Bring the solution to the boil to dissolve the agarose. Let the solution cool down to room temperature and add $2 \mu \mathrm{l}$ ethidium bromide stocks for $20 \mathrm{ml}$ gel solution. Stir the solution to disperse the ethidium bromide, and then pour it into the gel rack. Insert the comb at one side of the gel, about 5-10 mm from the end of the gel. When the gel has cooled down and become solid, carefully remove the comb. The holes that remain in the gel are the wells or slots. Put the gel, together with the rack, into a tank with 1 XTAE buffer. Add $5 \mu 1$ of Bromophenol blue to the $10 \mu 1$ of Sample and load it into the wells. Allow them to electrophoresis for a while at 100volts. Observe the gel under gel documentation system for the presence of DNA.

\subsection{Qualitative and Quantitative Analysis of DNA}

\section{Procedure}

Take $2 \mathrm{ml}$ Distilled water in a cuvette and calibrate the spectrophotometer at $260 \mathrm{~nm}$ as well as $280 \mathrm{~nm}$. Add $10 \mu \mathrm{l}$ of each DNA sample to $1990 \mu \mathrm{l}$ Distilled water and mix well. Use Distilled water as a blank in the other cuvette of the spectrophotometer. Note the $\mathrm{OD}_{260}$ and $\mathrm{OD}_{280}$ values on spectrophotometer.

Calculate the $\mathrm{OD}_{260} / \mathrm{OD}_{280}$ ratio. The concentration is calculated using the following formula

Concentration $=\mathrm{OD}_{260} \mathrm{X} 50 \mathrm{ug} / \mathrm{ml}$ X Dilution factor

A ratio between 1.8-2.0 denotes that the absorption in the UV range is due to nucleic acids. A ratio lower than 1.8 indicates the presence of proteins and/or other UV absorbers. A ratio higher than 2.0 indicates that the samples may be contaminated with chloroform or phenol. In either case $(<1.8$ or $>2.0)$ it is advisable to re-precipitate the DNA.

\section{Results and Discussion}

The endemic medicinal plants DNA preparations is the presence of polysaccharides and certain secondary metabolites, which have been observed to interfere with DNA isolation procedure and inhibit the activity of DNA modifying enzymes (Angeles et al. 2005; Padmalatha et al. 2006; Mishra et al. 2008; Yanging Hu et al. 2009). DNA extraction was improved by modifying some steps in the original Doyle's (Doyle and Doyle, 1987) CTAB method to remove these secondary metabolites. Samples were pretreated at $100^{\circ} \mathrm{C}$ to remove water-soluble contaminations. Buffer I was used to get purity and qualitative, qualitative DNA by removing cell wall debris, proteins, liquid and many secondary compounds at low speed centrifugation. DNA was further purified by removing polysaccharides with $\mathrm{CTAB} / \mathrm{NaCl}$ buffer in which DNA was soluble but polysaccharides were insoluble (Murry and Thompson, 1980). The RNAse treatment, the extracted DNA 


\section{Macrothink}

could be used for restriction and ISSR-PLR analysis, so it is unnecessary to purify the DNA with RNAse (Murry and Thompson, 1980). The $\mathrm{A}_{260} / \mathrm{A}_{280}$ absorbance ratio of extracted DNA was found to be free from polysaccharide, poly-phenols and tannins contaminants ranged from 2.2 to 2.8 within the high level of purity

Table 1 . The purity of DNA extract with modified CTAB method

\begin{tabular}{|l|l|l|l|l|l|}
\hline Sample & Name of the plant & $\mathbf{A}_{260}$ & $\mathbf{A}_{\mathbf{2 8 0}}$ & $\begin{array}{l}\text { Concentration } \\
(\boldsymbol{\mu} \mathbf{g} / \mathbf{m l})\end{array}$ & $\begin{array}{l}\text { Purity (A260/ } \\
\mathbf{A 2 8 0})\end{array}$ \\
\hline Sample 1 & $\begin{array}{l}\text { Pterocarpus } \\
\text { santalinus }\end{array}$ & 0.032 & 0.019 & 320 & 1.68 \\
\hline Sample2 & $\begin{array}{l}\text { Pimpinella } \\
\text { tirupatiensis }\end{array}$ & 0.021 & 0.014 & 210 & 1.5 \\
\hline
\end{tabular}

$\begin{array}{lllrr}123 \mathrm{M} & 456 & 1 & 23 \mathrm{M} & 456 \\ (\mathrm{a}) & & \\ & \end{array}$

Figure a. Extraction of DNA from plant sample with 100bp DNA marker on 1\% Agarose gel Lane: 1, 2, 3:- Pimpinella tirupatiensis Lane: M: 100bp DNA Marker

Lane: 4, 5, 6:- Pterocarpus santalinus

Figure b. Purified DNA with 100bp DNA marker on 1\% Agarose gel

Lane: 1, 2, 3:- Pimpinella tirupatiensis

Lane: M: 100bp DNA Marker

Lane: 4, 5, 6:- Pterocarpus santalinus

\section{Conclusion}

The modified CTAB method was proved to be an efficient method of DNA extraction from Pterocarpus santalinus and Pimpinella tirupatiensis samples and which is reliable compared to the standard extraction methods from other tissues like leaves.

Acknowledgements: The authors are thankful to the Criya Institute of Life Sciences, Balaji colony, Tirupati. 


\section{References}

Biradar, D., V. Patil, M. Kuruvinashetti, M. Biradar, Patil \& S. Yaradoni, (2005). Characterization of bamboo elite clones from Western Ghats of India using RAPD markers. Proceedings of the role of Biotechnology, March 5-7, Villa Gualino, Turin, Italy, pp.155-156.

Ranjan, S., G. Kishore, V. Jadon, J. Bhat \& S. Gupta (2010). Study on Phylogenetic relationship of an endangered plant Allum stracheyl using Method. Int.J. Biotechnol.Biochem, $6,735-742$.

Naidu, C. V. \& Mastan, M., (2001). Seed pretreatment methods to improve germination Red sanders (Pterocarpus santalinus Linn.F.). Indian J. For, 24(3), 342-343.

Angelers JGC, Laurena AC, \& Mendoza EMT. (2005). Extraction of genomic DNA from the lipid- polysaccharide-, and polyphenol- rich Coconut (Cocos nucifera L.). Plant Mol. Biol. Rep, 23, 297a-297i. http://dx.doi.org/10.1007/BF02772760

Murray MG, \& Thompson WF. (1980). Rapid isolation of high molecular weight plant DNA. Nucl. Acids Res, 8(9), pp.4321-4325. http://dx.doi.org/10.1093/nar/8.19.4321

Mishra MK. Ravi NS, Ram As, Sreenath HL, \& Jayarama. (2008). A simple method of DNA extraction from coffee seeds suitable for PCR analysis. Afr, J. Biotechnol, 7(4), 409-413.

Jenive Stella , P. Krishnamoorthy, \& A. Jamal Mohemed M. Anand. (2011). Free radical scavenging and antibacterial evaluation of Pterocarpus santalinus leaf In- vitro study. International Journal of pharmaceutical Sciences and Research, vol. 2, ISSN: 0975-8232.

Ravikumar, K., \& Ved, D. K. (2000). An Illustrated field guide for 100 red listed medicinal plants of conservation concern in Southern India (FRLHT), pp.308-312.

Latheef. S. A., Prasad, B., Bavaji, M., \& Subramanyam, G. (2008). A database on endemic plants at Tirumala hills in India. Bioinformation, 2, 260-262. http://dx.doi.org/10.6026/97320630002260

Padmalatha K, \& Prasad MNV. (2006) optimization of DNA isolation and PLR protocol for KAPD analysis of selected medicinal and aromatic plants of conservation concern from peninsular Indian Afr. J. Biotechnology, 5(3), 230-234.

Kacahapur, R., P. Salimath \& B. Reddy. (2009). Genetic diversity within sweet sorghum (sorghum bicolor (w) Moch) accessions as revealed by RAPD markers I. Maharastra Agric. Univ, 34, 38-42

Staden, V., J. Finnie, M. Moyo, S. Amoo \& M. Bairu, (2008). Optimizing DNA isolation from medicinal plants. S.A.fr. J. Bot, 74, 771-775.

Chopra RN Nayar SL \& Chopra IC, (1956). Glossary of Indian medicinal plants India CSIR, pp.171

Krishnaveni KS \& Srinivasa Rao JV, (2000). As isoflavone from Pterocarpus santalinus phytochem, 53, 605-606. 


\section{Macrothink}

Shankar, M.S., Sugumaran, T. Kalaiyarasu, \& N. Bubna, (2009). A rapid method for isolation of high quality DNA from leaves of Gmelina arborea (Roxb.) for molecular analysis. Int. J. Biotechnol. Appl, 1, pp. 16-19.

Yamping Hu, \& Xiaology Xie, (2009). An effective and low-cost method for DNA extraction from herbal drugs of Rheum tanguticum (Polygonaceae). African J. of Biotechnology, 8(12), 2691-2694

Doyle, J. J. \& J. L. Doyle, (1987). A rapid DNA Isolation procedure for small quantities of Fresh leaf tissue Phytochem. Bull, 19, 11-15

\section{Copyright Disclaimer}

Copyright reserved by the author(s).

This article is an open-access article distributed under the terms and conditions of the Creative Commons Attribution license (http://creativecommons.org/licenses/by/3.0/). 